\title{
Ethnic Conflict as a Risk Amplifier for Resurgent $P$. Vivax Malaria in Temperate Zones: A Case Study from the Caucasus Region.
}

Katherine Hirschfeld ( $\nabla$ tkhirschfeld@ou.edu )

University of Oklahoma https://orcid.org/0000-0001-8555-9177

Kirsten de Beurs

University of Oklahoma Norman Campus: The University of Oklahoma

Brad Brayfield

University of Oklahoma Norman Campus: The University of Oklahoma

Ani Melkonyan

University of Duisburg Essen - Campus Duisburg: Universitat Duisburg-Essen

\section{Research}

Keywords: malaria, Caucasus, Armenia, Azerbaijan, ethnic violence, refugees, emerging infectious disease

Posted Date: October 6th, 2020

DOI: https://doi.org/10.21203/rs.3.rs-79366/v1

License: (c) (i) This work is licensed under a Creative Commons Attribution 4.0 International License. Read Full License

Version of Record: A version of this preprint was published at Global Environmental Change on May 1st, 2022. See the published version at https://doi.org/10.1016/j.gloenvcha.2022.102495. 


\section{Abstract}

Background: One of the most protracted post-Soviet conflicts of the 1990s was a territorial dispute between Armenia and Azerbaijan over the contested Karabakh region. Years of ethnic violence led to the displacement of nearly a million refugees, as well as a public health crisis that included epidemics of malaria, diphtheria and other preventable diseases. Malaria is not usually considered a health risk in temperate climates, but seasonal epidemics were widespread throughout the Caucasus in the early decades of the twentieth century.

Methods: This paper combines qualitative historical research with geospatial analysis to explore how endemic malaria was controlled during the Soviet era, and how ethnic conflict reconfigured local ecologies to facilitate the re-emergence of $P$. vivax after the Soviet collapse in the 1990 s.

Results: This research reveals that ethnic conflicts have specific qualities that increase risks of infectious and vector borne disease outbreaks, even in places that have successfully achieved a modern health and mortality profile. The risk amplifiers of ethnic conflicts include 1) the creation of contested spaces controlled by separatists that are outside of any national public health surveillance system; 2) mass population movements and refugee outflows due to ethnic violence; and 3) changes in land use that expand potential mosquito breeding sites throughout the conflict zone.

Conclusions: Ongoing hostilities between Armenia and Azerbaijan, combined with the repopulation of key vector species (specifically An. sacharovi) lead us to conclude that contemporary populations in the Caucasus remain vulnerable to resurgent outbreaks of ethno-nationalist violence as well as the return of seasonal malaria, even after decades of successful control.

\section{Introduction}

Malaria is considered a tropical disease, but there is also a temperate or seasonal variety that can create significant population morbidity $(1,2,3,4$, $5,6)$. Epidemics of $P$. vivax coincided with planting and harvest seasons in the Caucasus in the early decades of the twentieth century, and these outbreaks incapacitated rural populations in ways that limited agricultural and industrial development (7). In 1924, health officials described seasonal malaria in the Caucasus as a "veritable scourge" that afflicted "up to eighty percent of the population" in the spring and fall (8).

An ambitious series of malaria control projects were undertaken by Soviet officials working together with the League of Nations and officers from the United States Public Health Service in the 1920s and 1930s. These involved large scale engineering projects as well as authoritarian vector control enforced at the community level. The social environment was also targeted for aggressive engineering to reduce the potential for internal conflict, and to integrate rural ethnic populations into the centralized Soviet system $(9,10)$. Taken together, these activities were successful in controlling seasonal malaria in the Caucasus for the remainder of the Soviet era $(4,11)$.

The collapse of the Soviet Union, however, reversed decades of public health success in just a few short years $(12,13,14,15)$. In the Caucasus region, these public health crises emerged in the context of ethnic conflict. These conflicts developed in the late 1980 s and early 1990 s, but should be considered examples of a contemporary variant of warfare: protracted conflicts between non-state actors, often fueled by ethnic violence and financed in part through environmental resource exploitation in the informal economy $(16,17,18,19,20)$. When left unchecked, these kinds of conflicts appear capable of reversing long standing public health successes and generating sustained epidemics of preventable infectious diseases. In the Caucasus these reversals were evident in the resurgence of seasonal malaria, along with parallel outbreaks of diphtheria, tuberculosis, measles, and viral hepatitis, all compounded by widespread nutritional stress, energy crisis and food insecurity (21).

Conflict-driven public health crises that emerge on the margins of failing or fragile states have been described by many researchers but are not fully theorized in the field of global health $(22,23,24,25)$, and European examples are rare. Many core textbooks and teaching materials remain influenced by twentieth century modernization theory and mortality transition theory, which assume that geopolitical boundaries are fundamentally stable, and that countries that have achieved a modern mortality profile are not likely to see dramatic reversals to pre-modern health conditions (26, 27). There is not a robust vocabulary to explain the kinds of health crises that develop in regions fractured by ethnic conflict or in the aftermath of political collapse. This paper presents a longitudinal case study of malaria control in the Caucasus through the conflict years of the 1990 s with the goal of exploring how public health crises emerge and expand in regions destabilized by ethnic warfare or other conflicts between non-state actors.

\section{Research And Research Methods}

The Karabakh conflict developed in the late 1980s and remains unresolved. Hostilities were frozen by a cease fire agreement in the mid 1990s, but skirmishes have continued to erupt in border areas and access to the region is limited $(28,29)$. For these reasons, this project developed multiple indirect methods for researching the resurgence of epidemic malaria. These include qualitative research in historical document collections and analysis of remote sensing data.

These indirect methods were supplemented with a small number of informal interviews with regional specialists, public health professionals, environmental scientists, journalists, plus a review of secondary sources. A site visit was undertaken to Armenia in the summer of 2018 , and several additional interviews were conducted with environmental health professionals in various government ministries. The geospatial analysis included development of specific methods to detect changes in surface water, agriculture and overall land use patterns (30). We also mapped the historical 
malaria occurrences in Russia and the Caucasus for 1922 and for the conflict and post-conflict period between 1991 and 2003 . In addition, we calculated the topographic wetness index as an indicator of environmental wetness which is associated with increased habitat for malarial mosquitoes.

\section{Environmental Dynamics of P. vivax Malaria}

Malaria is not a single disease, but a diverse group of blood parasites with different evolutionary lineages, variable mammalian hosts and multiple species of mosquito vector (1). P. falciparum or tropical malaria produces the most severe pathology in humans and is responsible for the majority of global deaths. P. vivax, on the other hand, is a seasonal variant that remains dormant in human hosts during winter months, then re-emerges in transmissible form when mosquitos re-appear in the spring (6). While seasonal malaria is rarely fatal, it can produce significant population morbidity, especially in agricultural communities or immunologically naive populations (31).

$P$. vivax is also the most globally prevalent form of malaria, with approximately 2.5 billion individuals at risk worldwide (32). There are potentially serious health complications, including anemia, jaundice and immune system dysfunction $(33,34)$. Second order effects of widespread $P$. vivax infection include regional food shortages, poverty, economic burdens and delayed cognitive development in children (35). There is currently no vaccine against any form of malaria, and drug treatments for $P$. vivax can be complicated by ancestral genetic adaptations such as G6PD deficiency $(1,33)$. Transmission dynamics, patterns of host immunity, and parasite life cycle variations of $P$. vivax are still not fully understood, and for these reasons some researchers have described $P$. vivax as a "neglected tropical disease of major global importance" (36).

\section{Twentieth Century Modernization And Soviet Malaria Control}

The Soviet Union consolidated its territorial control of the Caucasus republics during the 1920s.

At that time, malaria was prevalent throughout the region, and co-circulation of $P$. vivax and $P$. falciparum created large overlapping epidemics that severely constrained Soviet colonization and industrial development programs. Debilitating malaria outbreaks among Russian troops entering the Caucasus from northern latitudes made it difficult for Soviet authorities to consolidate territorial control. In 1923 one public health report estimated approximately 680,929 cases of malaria throughout the USSR, and these were considered to represent only about one fifth of the total cases

The most severe malaria outbreaks in the Soviet Union were concentrated in river basins that drained the mountainous Caucasus region. The Bashkir region of the USSR, for instance, was estimated to have over five thousand cases of malaria per 100,000 inhabitants in 1923 , up from 2529 cases per 100,000 in 1922. In the lower Caucasus, there were estimated to be over one million cases of malaria in 1923, with most going untreated due to shortages of quinine. In Armenia, malaria was described as the "most important communicable disease," in the 1920s, comprising approximately fifty percent of the total infectious disease burden.

In keeping with the assumptions of twentieth century mortality transition theory, malaria and other preventable infectious diseases were viewed as relics of the pre-modern past by public health professionals working in the 1920s and 1930s $(37,38)$. Soviet, North American and European health authorities embraced variants of this progressivism and committed significant resources to collaborative state-sponsored public health work in the first half of the twentieth century. Diseases associated with rural poverty were viewed as impeding human progress, and specifically targeted for aggressive eradication efforts. As malariologist L. W. Hackett stated in the 1930s, "The consensus of opinion was that this disease [malaria], like typhus and plague, was an anachronism among advanced people in modern times and would soon cease to be of importance in the temperate zone" (39).

The convergence of public health planning goals between the United States, Europe and the Soviet Union led to a series of collaborative programs in the decades preceding the Cold War. The Epidemic Commission of the League of Nations was formed in 1920 and combined public health expertise from member nations to eliminate diseases associated with poverty. In 1923 a subgroup of six malariologists developed an internal working group that later became known as the League of Nations Malaria Commission. In 1928 this group sponsored a tour of successful malaria control programs in the southern United States so that environmental engineers and vector control specialists in other countries could apply these techniques to malarious regions in Europe and the Soviet Union. By 1933 the group included over fifty experts from various fields, who shared epidemiological reports and collaborated in clinical research and drug trials to document successful eradication and control techniques.

Officials in the USSR also developed uniquely Soviet methods to expand rural health initiatives. State enterprises, for instance, were required to develop plans for mosquito eradication and to control mosquito breeding at construction sites (40). From 1946-1951, a DDT spraying campaign extended over nearly 200 million square kilometers in the USSR. The centralized Soviet medical system was also able to deploy teams of specialists (including etymologists, doctors, nurses and hydro-technicians) to work in malarious regions, and these capabilities also contributed to overall reduction in malaria prevalence. According to one researcher, overall malaria rates declined from 43.1 per 10,000 in 1950 to 9.8 per 10,000 in 1952 (40).

Much of this anti-malaria work coincided with the growing centralization of political power by Joseph Stalin and increasing censorship of negative health data in the USSR. By the early 1930s, Soviet health officials were under great pressure to report progress consistent with the goals outlined in 
the first and second Five Year Plans. These pressures could be extreme: doctors who diagnosed patients with typhus after Stalin declared the disease eradicated were arrested and accused of spreading anti-Soviet propaganda (41). All Soviet health data from the Stalin era and beyond should be viewed with caution, so it is difficult to pinpoint exactly when malaria began to recede from the Caucasus. But later research suggests major declines during the 1940s and 1950s (42,40). Malaria was formally declared eradicated in Armenia in 1963 (43).

\section{Ethnic Groups And Political Boundaries In The Ussr}

In the 1920s and 1930s, Soviet social engineers were also eager to transform the "backward" cultural terrain of the Caucasus from a clan-based, rural, religious peasantry into a modern, secular Soviet outpost. Soviet social theory was explicitly evolutionist and ethnic identity was understood to represent an archaic or "pre-Soviet" stage of human social development $(44,10,20)$. As a result, overt representations of ethnic identity in the Caucasus (including religious practice, traditional clan kinship systems, land tenure, inheritance customs, languages and traditional dress) were restricted or reconfigured by Soviet authorities. The result of these trends was an authoritarian reconfiguration of the social order that included the elimination of traditional ethnic territorial divisions and the creation of new administrative boundaries under the central authority of the USSR. According to one scholar, Soviet governance was originally welcomed by residents of the region, as it promised a respite from longstanding ethnic violence (45).

Three levels of ethnopolitical governance were established for the Caucasus by the USSR: 1) Soviet Socialist Republics (SSR), which were considered semi-sovereign countries in theory if not in practice; 2) Autonomous Republics (ASSR), which were considered "national states" without individual sovereignty and held more tightly under the control of Moscow, and 3) Autonomous oblasts (AO), which were located within larger Soviet states but granted some level of local governance (20). Some of these units were more ethnically homogenous than others, but all included multiple ethnic groups forced into an uneasy coexistence under the threat of Soviet military repression.

Many of these Soviet administrative territories changed over time, with phases of consolidation accompanied by cycles of "cruel repressions" (10). But they were all fundamentally artificial and designed to weaken ancestral ethnic affiliations. The stubborn persistence of ethnicity in the region eventually led to more violent forms of repression. By the middle of the Stalin era, the USSR resorted to wholesale deportation of ethnic groups viewed as anti-Soviet. Thousands of Chechens, Tatars, Kalmyks, Balkars, Ingush and others were expelled from the Caucasus and relocated to sparsely populated areas of Central Asia in the 1940 s $(46,47,9,20)$. By the early 1950 s, a total of 3.5 million Soviet citizens had been forcefully removed from their ancestral homelands (17).

According to one historian, over twenty percent of exiled Chechens and Ingush died during the first four years of exile in Central Asia (48). The same pattern was repeated with exiled Crimean Tatars in 1944, with over 70,000 of 190,000 deportees dying en route due to poor health and sanitation conditions in transport trains. Other ethnic groups were spared physical dislocation but subjected to "ethnocide" or cultural erasure "because they were seen as too small and irrational" to fit into Stalin's idea of a modernizing Soviet state (48).

Armenia was the most ethnically homogenous Soviet SSR, with Armenians constituting over ninety percent of the population (20). This demographic pattern contributed to a stronger fusion of ethnicity with national identity in Armenia than in other areas of the Caucasus. Armenian nationalism was further bolstered by historical trauma of the Armenian genocide in the early twentieth century, when over one million Armenians were killed or driven out of the Ottoman Empire (20). In neighboring Georgia (also an SSR), by contrast, the population was approximately seventy percent ethnic Georgians, with significant minority groups of Dagestanis, Ossetians, Abkhazians, Azeris, and others. Azerbaijan, on the other hand, was approximately eighty percent Azeri with subgroups of Dagestanis, Tatars, Lezgins, Kurds and Turks (20).

\section{Ethnic Conflict And Soviet Collapse, 1988-1994}

The Nagorno-Karabakh region extends as a long corridor between Armenia and Azerbaijan. This area was historically populated by ethnic Armenians but placed under the control of the Azerbaijan SSR by Soviet authorities as a way to weaken Armenian nationalism. This led to repeated petitions by Armenian officials for reunification. But appeals to ethnonationalism were suppressed by Soviet authorities in the 1960s and 1970s. In the 1980s, however, Soviet Premier Gorbachev signaled his intentions to reduce political repression in Soviet society though the twin programs of Glasnost and Perestroika. These policy shifts coincided with an administrative decision by Soviet authorities to transfer land from an Armenian kolkhoz in Karabakh to one under Azeri control.

These developments increased tensions in the region at a time when Soviet authorities were less inclined to suppress dissent. Outbreaks of ethnic violence were reported in Karabakh around this time, though specific details are lacking in available historical records. According to one analyst, ethnic militias began to form in 1988 and engaged in rounds of reciprocal ethnic cleansing in several Karabakh villages. These militia groups were not professional soldiers but were described as rural populations armed with little more than "improvised weapons" (49). One scholar has estimated that before 1990, the total number of combatants on each side in the Karabakh conflict was only around two hundred (20), and many were composed of extended families rather than professional soldiers (50). 
Reports of ethnic violence in Karabakh reverberated in urban areas and triggered painful cultural memories of past conflicts and historical grievances. According to one group of researchers, Armenians in the Karabakh region had experienced decades of abuse at the hands of the Azeri government during the Soviet period. "Resources for economic development have been withheld or diverted elsewhere...and Armenian cultural and educational facilities in the [Karabakh] province have been systematically underfunded and restricted" (51). The Armenian genocide of the early 20th century also created a lasting cultural trauma that generated "a mass trauma" that in turn led to mass mobilization of violence during the Soviet collapse (52).

In February 1988, twenty-six Armenians were killed in the Azeri town of Sumgait, leading over a million people to gather in protest in Yerevan. This protest led to new violence against Armenian populations in Azerbaijan, followed quickly by retaliatory measures against Azeris and other ethnic minorities in Armenia, including forced expulsion of Muslim, Azeri, and Kurdish populations (50). Cities in Azerbaijan were suddenly faced with a growing influx of impoverished refugees, many of whom took out their anger and resentment on local Armenian populations.

Another blow to peace and stability came in the form of a massive earthquake that struck Armenia in December 1988, killing 25,000 Armenians and destroying the cities of Spitak and Stepanavan. Hundreds of thousands in the region were left homeless, just as Soviet power began to contract, leaving peripheral areas with weak or uncertain governance. By the summer of 1989, Karabakh Armenians began an informal secession from the USSR and created their own political structures, including a Congress. In the words of one journalist, "the [Karabakh] dispute galvanized both Armenians' and Azerbaijanis' movement for de-colonization from Moscow" (53). New waves of persecuted Armenians fled Azerbaijan, with over 180,000 arriving in the first half of 1989. Over 160,000 Azeris were correspondingly displaced from Armenia during this time (50). Militia groups in Karabakh expanded and allegedly hardened their tactics against one another.

In January 1990, the Soviet government made a final attempt to suppress separatism and ethnic fragmentation in Karabakh, and troops were sent to Baku. Hundreds of thousands of protestors marched against this new wave of repression, as well as against ethnic violence. Armenians in Baku were targeted in these demonstrations, though it is unclear by whether by Soviet troops, Azeri civilians or both. Hundreds of protestors were arrested or killed, intensifying the regional push for independence (20). Similar events were unfolding in neighboring Georgia, with separatist violence erupting between various minority groups, as well as with Soviet authorities $(9,20)$.

By the summer months, the Armenian national movement effectively ended Soviet rule in Armenia. Soviet forces continued to support Azeri leadership and worked to punish Armenian nationalists and disarm militias in the Karabakh region. An economic blockade was put in place to cut off energy supplies to Armenia, further escalating tensions. New waves of ethnic violence and displacement occurred through 1991, with Armenians deported from villages in Karabakh and their property and agricultural lands redistributed to Azeri refugees (50). Armenian militias in Karabakh gained additional support from the newly established Armenian government and began to retaliatory raids against Azeri settlements.

The Soviet Union underwent its final collapse in the summer of 1991, though informal reports suggest that Soviet troops stationed in the Caucasus were "self-privatizing" or selling their services and weapons to local militias in the late 1980s (50). This further destabilized the Karabakh region and left ethnic militias to function as the default security agencies, now armed with sophisticated Soviet military weapons. The conflict intensified into a "full-fledged if undeclared war" fueled by an aggressive spirit of ethnonationalism. As with other post-Soviet conflicts there were also "violent entrepreneurs" who had been active in the informal economy of the USSR and sought to profit from the hostilities $(53,50,54,55)$.

The Karabakh conflict was one of over twenty ethno-territorial conflicts that flared up in the Caucasus region in the 1990s. Seven of these expanded into actual wars with widespread violence $(56,54)$. During this time, Russia itself was also destabilized by internal conflicts between rival organized crime groups. Homicide rates soared as criminal gangs-many with ties to the KGB and other security services-fought one another for market share of newly privatized industries $(57,58,59)$

From 1992-1994 the Karabakh region endured repeated cycles of bombing, ethnic violence, looting, and attacks on civilians. By the time a cease fire was enacted in 1994, over 350,000 people had been expelled from their homes, and agricultural production, transportation and basic institutions of commerce were severely disrupted or destroyed $(60,53)$. Approximately 200,000 Azerbaijanis fled Armenia in the first phase of conflict (19881989), and another 500,000 left the Karabakh region during the peak conflict years of 1992-1994, leaving Azerbaijan with one of the highest rates of displaced people in the world (53). A similar number of Armenians were also displaced, and Azerbaijan ultimately lost about twenty percent of its pre-war territory (20). An estimated 30,000 people died in the hostilities with thousands more suffering "untold misery" from disease, impoverishment, displacement, cold, hunger and looting (50).

\section{Epidemic Malaria And Ethnic Conflict}

The exact origin of the malaria epidemic that struck Armenia and Azerbaijan in the 1990s remains unclear. There were reports of soldiers from Afghanistan and Chechnya fighting in the region, and speculation that these individuals could have imported malaria into the conflict zones (47; 50). Cases of locally acquired $P$. vivax were only recognized in Armenia after the cease fire agreement in 1994. At that time, the Armenian Ministry of Health received assistance from the U.S. Centers for Disease Control and the World Health Organization to re-establish malaria control measures $(42,61)$. According to one Armenian researcher, over $90 \%$ of the documented cases of $P$. vivax were found in refugees from the Karabakh region 
(42). The epidemic in Armenia continued to expand, with over one thousand total cases reported in 1998, about half of which were locally acquired. A retrospective analysis by Azeri researchers indicates a peak in malaria transmission in Azerbaijan in 1996, with over thirteen thousand cases recorded, and a gradual decline lasting through the remainder of the 1990s, with full elimination achieved in the early 2000 s (4).

The epidemic spilled over into neighboring Georgia, which reported hundreds of cases in the early 2000s after years of internal conflict (4, 20). Researchers have acknowledged these case counts are likely to be underestimates, due to pervasive instability and chaos. Neither analysis, however, examines the Karabakh epidemic in the context of systemic Soviet collapse and the expansion of ethnic territorial conflict. Instead, the uncertain status of the Karabakh region remains embedded in public health scholarship, with Azeri researchers describing the region as "occupied territories," (4), and Armenian researchers naturalizing the reincorporation of Karabakh into the political geography of Armenia (42).

\section{Results}

This case study presents a historical and spatial analysis of the resurgence of $P$. vivax malaria in the southern Caucasus region during the armed conflict between Armenia and Azerbaijan. The historical documents reveal an important insight: controlling epidemic malaria in the Caucasus in the 1920s and 1930s required decades of authoritarian reconfiguration of the social environment and suppression of ethnic identity, as well as large scale efforts to re-engineer the physical environment through improved drainage and mosquito control. Conversely, the armed conflict that erupted in the late 1980s changed the social and physical environment very quickly, so that malaria was able to re-emerge in epidemic form by the time of the cease fire agreement in 1994.

Closer examination of the armed conflict itself reveals the importance of informal ethnic militias in this process of environmental reconfiguration. Ethnic militias operate differently than regular state-sponsored armed groups, and these differences have important insights for population health. Irregular armed groups, for instance, operate outside the control of established nation-states and often rely on activities in the informal economy for financing. In the Caucasus these activities included illegal logging, smuggling and destruction of properties owned by ethnic rivals (54, 56). These activities took place in an ungoverned space created by the collapse of the USSR and the reconfiguration of national political boundaries. Separatist spaces by definition have no public health surveillance systems so that infectious and vector borne diseases can circulate invisibly for some time. Ethnic violence in the Caucasus conflict also led to massive population displacement with millions of refugees flowing out of the conflict zone and into more stable regions of Armenia and Azerbaijan. These population flows effectively moved malaria, diphtheria and other infectious diseases out of Karabakh and into major metropolitan areas. The combination of depopulation and territorial uncertainty led to high rates of abandoned farmland in Karabakh, and these changes in land use further expanded mosquito breeding sites in the area.

\section{Discussion}

Researchers who study political collapse have noted that the process of state failure often begins with territorial contraction or "loss of control over political and economic space" on the part of the national government (62). Contraction of political boundaries accelerates the process of state failure, as peripheral regions establish their own informal governance systems under the control of non-state actors. Over time, the national government loses legitimacy as the state can no longer claim a monopoly on violence due to the fragmentation of cartographic space (63, 64, 65). In the case of many post-Soviet conflicts in the Caucasus and elsewhere, there was a return to "pre-modern" forms of social and economic life, and a rejection of the secular multiculturalism and bureaucratic administration that defined modern Soviet society.

One Russian social scientist used the term "demodernization" to describe the social effects of armed conflict in Chechnya and other post-Soviet states (66). These pre-modern conditions developed in part due to the exodus of intellectuals and professionals from conflict zones, depriving society of, "those people capable of implementing the agenda of modern life through society's key institutional structures-such as economic and political administration, education and culture and social security" (66). Tishkov goes on to state that people who remained conflict zones experienced rapid transformation of the social and natural world, with kinship re-emerging as a dominant force of social organization, and non-state violence used to enforce or enhance traditional rules and norms. In this context, ethnic identity and religious practice emerged as expansive forces of social solidarity.

Tishkov has also described demodernization as "difficult to escape" once it has taken hold in a region (66). This variant of warfare is not constrained by the rules of combat that prevail between nation-state armies. Instead these armed groups blur lines between combatants and civilians, and often attack core institutions of modern life in the built environment, including schools, clinics and hospitals (54, 66). In the Chechen conflict, for instance, civilian casualties "exceeded those of both Russia's army and the insurgents' battalions and guerrillas" (66). The homicide rate in Chechnya also increased by seven hundred percent between 1991-1993, signifying an overall breakdown in security and a return of ancestral clan-based systems that mobilize entire kin groups in cycles of retaliatory attacks (66).

The Karabakh conflict did not generate the same level of protracted internal violence as the conflict in Chechnya. But there are some important similarities. The early ethnic militias that developed in the late 1980s and early 1990s were funded in part by natural resource extraction that disrupted agricultural activities and led to significant loss of forest cover. Remote sensing analysis of land use patterns in the Karabakh conflict zone, for instance, reveal over sixty percent of agricultural lands were abandoned within a short period of time, indicating a massive "socioeconomic 
shock" (60). Abandoned agricultural lands are likely to increase mosquito breeding sites as irrigation systems are not maintained and stagnant pools of water can result. A group of entomological researchers has also described significant repopulation of $A$. sacharovi (a key mosquito vector for $P$. vivax) in parts of Armenia since the 1990s (68).

Spatial imaging also reveals high rates of forest disturbance in parts of the conflict area (60). There are anecdotal reports that several of the early militias in the Karabakh region financed their insurgencies by exploiting timber resources, and in some areas forest disturbance rates reached almost twenty percent (60). Refugees and other impoverished populations in Armenia were known to have harvested timber in rural and urban areas to burn for heat following an energy blockade imposed by Azerbaijan in $1991(69,70)$. These environmental disruptions were exacerbated by militia attacks on schools, hospitals and homesteads during the conflict, accelerating the exodus of refugees from the region (71).

Outbreaks of measles and diphtheria that emerged in Armenia during the conflict were successfully controlled by a vaccination campaign facilitated by international aid and humanitarian assistance agencies. Malaria control, however, is more complex. There is no vaccine for malaria, and successful prevention requires a complex array of activities that require a stable government with full territorial control, significant economic resources and strong political will-in other words, a modern nation-state. These conditions were irregular and uneven in the post conflict period, when both Armenia and Azerbaijan were fragile new states struggling to establish national governments following the cease fire agreement in 1994.

Over time, Armenia and Azerbaijan did re-establish themselves as formal nation-states after the cease fire agreement. Their new national governments then received assistance from the World Health Organization along with several NGOs to re-establish disease surveillance, improve drainage, rebuild irrigation systems and renew mosquito spraying. By the early 2000s, political administration and public health infrastructure were developed enough to control malaria once again. Armenia declared itself malaria free in the early 2000s (61), and Azerbaijan in the mid 2010s (74).

But the territorial status of Karabakh is still unresolved, and the potential for new outbreaks of ethnic violence remains high. In the spring and summer of 2020, at least sixteen people were killed in border skirmishes around Karabakh, sparking large public demonstrations and calls for retaliatory attacks. Armenia and Azerbaijan have continued to build up forces around the Karabakh region, and now have armies of drones capable of destroying one another's vital infrastructure, including water and power systems. In June 2020 the Azerbaijani Defense Minister even threatened to attack an Armenian nuclear power station in order to create a "Chernobyl type catastrophe" (75). In September 2020, hostilities broke out again with one news agency reporting "fierce fighting" across the region (76).

These ongoing tensions suggest that Armenia and Azerbaijan remain vulnerable to new outbreaks of armed conflict and re-emergence of $P$. vivax malaria. According to our newly constructed topographic wetness index (see Fig. 5), for instance, many areas of Azerbaijan remain suitable for mosquito breeding based on analysis of yearly rainfall and surface water accumulation. Many Karabakh villages are still underpopulated and a good deal of farmland remains uncultivated. Any future interruptions in disease surveillance or vector control activities in the region are likely to create new opportunities for $P$. vivax to become re-established in the region.

\section{Conclusions}

This case study highlights the way ethnic conflict generated resurgent epidemics of preventable infectious and vector borne disease in the southern Caucasus region in the 1990s.

Our analysis has shown how ethnic separatist movements are different from other kinds of conflicts. Separatists, for instance, seek to create semiautonomous zones or new states carved out of existing geography of an established nation-state. These conflicts weaken the central government and create territorial blind spots for public health surveillance. The re-introduction of $P$. vivax malaria in the contested Karabakh region originally went unrecognized due to the interruption of vector control and disease surveillance that occurred during the Soviet collapse. As the conflict intensified, dispossessed refugees from the Karabakh conflict zone spread malaria into the more stable regions of Armenia and Azerbaijan, where it persisted for years before it was finally controlled.

The Karabakh conflict itself was frozen by a cease fire agreement in 1994, and since that time the region has remained underpopulated. The uncertain status of Karabakh has led to abandonment of farmland and increased surface water accumulation-trends that have created expansive new habitat for Anopheles mosquitos. These environmental changes, coupled with unresolved nature of the conflict itself, suggest that the health crises of the 1990s could re-emerge in the 2020s. Furthermore, the tremendous ethnic diversity of the entire Caucasus area combined with the long history of unstable political geography means that other multi-ethnic countries in the region may be at risk for similar outbreaks of internal armed conflict, followed by demodernization and resurgent $P$. vivax malaria. Recent research has revealed that ethnic violence and other intra-state conflicts now outnumber traditional nation-state conflicts by a substantial margin in many parts of the world (19). Researchers should be aware that these aggregate changes in global conflict patterns could generate new outbreaks of preventable infectious and vector borne diseases, even in temperate regions that have achieved a modern health and mortality profile for many decades.

\section{Abbreviations}


Nagorny Karabakh

SSR

Soviet Socialist Republic

ASSR

Autonomous Soviet Socialist Republic

AO

Administrative Oblast

\section{Declarations}

\section{Ethics Approval and Consent to Participate}

Not applicable. All members of this research group completed the University of Oklahoma's Institutional Review Board Training for research with human subjects in 2018.

\section{Consent for Publication}

Not applicable. This research paper does not contain images of individuals or qualitative interview information from any individual research subjects.

\section{Availability of Data and Materials}

Data for Figure 1 was acquired from the Electronic Repository of Russian Historical Statistics (RISTAT) from the International Institute of Social History. Data was acquired from the RLC and Regional Boundary for the Former Soviet Union dataset. The dataset was derived from state and regional boundaries from the 1:3 million scale ESRI dataset. KC: Karachay-Cherkessia; KB: Kabardino-Balkaria; Cl: Checheno-Ingushetia.

Data for Figure 2 (Caucasus administrative boundaries) were downloaded from the freely available GADM.ord dataset. Malaria rates were obtained from League of National Malaria Commission reports located at the National Archives and Records Repository in College Park, Maryland.

Data for Figure 3 were taken from the Geo-referencing of Ethnic Groups data (GREG) derived from Wedmann et al. (2010). This dataset is digitized from the Atlas Narodova Mira (ANM, Bruk \& Apenhenko, 1964) which is the result of a very large initiative by ethnographers in the Soviet Union who set out to chart ethnic groups world-wide in the 1960s.

Data for Figure 4 were retrieved from GADM.org and conflated with the Soviet Union borders. Karabakh border from ESRI disputed borders dataset. Nagorno-Karabakh line of contact line from the website of the Armenian Ministry of Foreign Affairs (digitized on GitHub by https://github.com/mkudamatsu/data_karabakh-map). Refugee camp locations obtained from United Nations Refugee Agency (UNHCR).

\section{Competing Interests}

Not applicable. The authors declare that they have no competing interests.

\section{Funding}

This research was supported by the NASA: Land-Cover/Land-Use Change project entitled "Land use patterns and political instability as predictors for the re-emergence of malaria in the Caucasus" to Kirsten de Beurs and Katherine Hirschfeld. Project number: 16-LCLUC16-2-0017

\section{Author's Contributions}

$\mathrm{KH}$ visited archival collections in the USA, compiled relevant historical documents, contacted area studies specialists, and consulted with epidemiologists, journalists and others who were present in Armenia and Azerbaijan during the conflict. KH drafted the initial manuscript.

$\mathrm{KdB}$ constructed maps from LANDSTAT data and used historical data to create malaria prevalence maps for the Caucasus region. KdB also developed tools for the construction of the topographic wetness index. KdB conducted a site visit in the Caucasus together with our Armenian collaborator (AM) in the summer of 2018. KdB offered input and edits to the initial manuscript, maps and legends.

BB offered edits, corrections and input on the initial draft of the manuscript.

AM provided insight about the history of conflict in Armenia during the site visit in 2018, and worked to provide translation of Armenian language materials to the research group, as well as facilitating introductions to Armenian health professionals. AM provided edits and suggestions on the initial draft of this manuscript. 


\section{Acknowledgements}

Not applicable

\section{Author's Information}

$\mathrm{KH}$ is a Professor of Medical Anthropology in the Department of Anthropology at the University of Oklahoma

KdB is President's Associates Presidential Professor, Department of Geography and Environmental Sustainability, University of Oklahoma

BB is a PhD student in the Health and Human Biology Program, Department of Anthropology, University of Oklahoma

AM is Associate Professor, Center for Logistics and Traffic, Joint Center Urban Systems, University of Duisberg-Esen, German

\section{References}

1. Carter, R. and Mendis, K. 2002 Evolutionary and Historical Aspects of the Burden of Malaria. Clinical Microbiology Reviews, 15(4):564-594.

2. Carlton, J. Das, A., Escalente, A. 2013 Genomics, Population Genetics and Evolutionary History of Plasmodium vivax. Advances in Parasitology, (81):203-220

3. Oshagi, M.A., Vatandoost, H., Gorouhi, Al, Abai, M.R., Madjidpour, A. Arshi, S., Sadeghi, H., Nazari, M., Mehravaran, A. 2011 Anopholine Species Composition in Borderline of Iran-Azerbaijan. ACTA Tropica 119:44-49.

4. Mammadov, S. Gasimov, E., Kurdova-Mintcheva, R. and Wongsrichanalai, C. 2016 Elimination of Plasmodium vivax Malaria in Azerbaijan. American Journal of Tropical Medicine and Hygiene, 95(supplement 6):78-86.

5. Sachs, J. and Malaney, Pia 2002 The Economic and Social Burden of Malaria. Nature, 415:680-685.

6. White, M. 2011 Determinants of Relapse Periodicity in Plasmodium vivax Malaria. Malaria Journahttps://malariajournal.biomedcentral.com/track/pdf/10.1186/1475-2875-10-297. Accessed 18 June 2020.

7. 7. Public Health Reports 1913 Malaria in Russia: Its Prevalence and Geographic Distribution, 28(5):206-207.

8. 8. Public Health Reports 1924 Prevalence of Disease, Foreign and Insular. 39(5):220-230.

9. King, C. 2008 The Ghost of Freedom: A History of the Caucasus. Oxford: Oxford University Press.

10. Tishkov, V. 1997 Ethnicity, Nationalism and Conflict in and After the Soviet Union. London: Sage Publications.

11. Romi, R. Boccolini, D. Hovanesyan, G, Grigoryan, M., Di Luca, M., and Sabatinelli, G. 2002 Anopheles sacharovi (Dipteria: Culicidae): A Reemerging Malaria Vector in the Ararat Valley of Armenia. Journal of Medical Entomology, 39(3):446-450

12. Fituni, L. 1995 The Collapse of the Socialist State: Angola and the Soviet Union. In, Zartman, W., ed. Collapsed States: The Disintegration and Restoration of Legitimate Authority. Boulder: Lynne Reinner, pp. 143-156.

13. Garrett, L. 2000 Betrayal of Trust: the Collapse of Global Public Health. New York: Hyperion.

14. Shkolnikov, VM and Chervyakov, VV 2000 Policies for the Control of the Transition's Mortality Crisis in Russia. Moscow: United Nations Development Program, Transnational Family Research Institute.

15. Zugar, A. 2000 Infectious Diseases Rising Again in Russia. New York Times. http://www.nytimes.com/learning/students/pop/001206wodwednesday.html. Accessed 20 August 2020.

16. Andreson, P. 2011 Blue Helmets and Black Markets: The Business of Survival in the Siege of Sarajevo. Ithaca: Cornell University Press.

17. Bunker, R. 2014 Public Looting for Private Gain: Predatory Capitalism, MNCs and Global Elites, and Plutocratic Insurgency. In, Global Criminal and Sovereign Free Economies and the Demise of Western Democracies. R. J. and P. L. Bunker, Eds. London: Routledge, pp. $134-187$.

18. Mandic, D. 2020 Gangsters and Other Statesmen. Princeton: Princeton University Press.

19. Muggah, R. and Sullivan, J. 2018 The Coming Crime Wars. Foreign Policy, https://foreignpolicy.com/2018/09/21/the-coming-crime-wars/. Accessed 26 May 2020.

20. Zurcher, C. 2007 The Post-Soviet Wars: Rebellion, Ethnic Conflict and Nationhood in the Caucasus. New York: New York University Press. 
21. Shapiro, M. 1993 Armenia's Good Life Lost to Misery, Darkness, Cold. Washington Post, https://www.washingtonpost.com/archive/politics/1993/01/30/armenias-good-life-lost-to-misery-darkness-cold/52d00f30-29bb-4508-9fbabf543000e8ea/. Accessed 26 May 2020.

22. Foghammer, L., Jang, S., Kyzy, G. Weiss, N., Sullivan, K., Gibson-Fall, F. and Irwin, R. 2016 Challenges in Researching Violence Affecting Health Service Delivery in Complex Security Environments. Social Science and Medicine, 162:219-226.

23. Furst. T. Raso, G., Acka, C. Tschannen, A., N'Goran, E., Utzinger, J. 2009 Dynamics of Socioeconomic Risk Factors for Neglected Tropical Diseases and Malaria in an Armed Conflict. PLOS Neglected Tropical Diseases, 3(9). https://www.ncbi.nlm.nih.gov/pmc/articles/PMC2731884/. Accessed 29 May 2020.

24. Ghobarah, H. Huth, P. and Russett, B. 2004 The Post-War Public Health Effects of Civil Conflict. Social Science and Medicine, 59:869-884.

25. Price-Smith, A. 2008 Contagion and Chaos: Disease, Ecology and National Security in the Era of Globalization. Boston: MIT Press.

26. Gilman, N. 2003 Mandarins of the Future: Modernization Theory in Cold War America. Baltimore: Johns Hopkins University Press.

27. Omran, A. 2005 The Epidemiological Transition: A Theory of the Epidemiology of Population Change. The Milbank Quarterly, 83(4):731-757.

28. Crisis Group 2017 Nagorno-Karabakh's Gathering War Clouds. https://www.crisisgroup.org/europe-central-asia/caucasus/nagorno-karabakhazerbaijan/244-nagorno-karabakhs-gathering-war-clouds. Accessed 17 June 2020.

29. Crisis Group 2019 Digging Out of Deadlock in Nagorno-Karabakh. https://www.crisisgroup.org/europe-central-asia/caucasus/nagornokarabakh-conflict/255-digging-out-deadlock-nagorno-karabakh. Accessed 17 June 2020.

30. Worden, J. and de Beurs, K. 2020 Surface Water Detection in the Caucasus. International Journal of Applied Earth Observation and Geoinformation. https://www.sciencedirect.com/science/article/pii/S0303243420301495?via\%3Dihub. Accessed 19 June 2020.

31. Bassat, Q., Velarde, M., Mueller, I., Lin, J., Leslie, T., Wongsrichanalai, C., and Baird, J. 2016 Key Knowledge Gaps for Plasmodium vivax Control and Elimination. American Journal of Tropical Medicine and Hygiene, 95(supplement 6):62-71.

32. Anvikar, A., van Eijk, A., Shah, A., Upadhyay, K., Sullivan, S., Patel, A., Joshi, J., Suchi, T., Ranvir, S. Carlton, J. Gupta, H., and Wassmer, S. 2020 Clinical and Epidemiological Characterization of Severe Plasmodium vivax malaria in Gujarat, India. Virulence, 11:1, 730-738.

33. Bassat, Quique, Velarde, Mar, Mueller, Ivo, Lin, Jessica, Leslie, toby, Wongsrichanalai, Chansuda, and Baird, J. Kevin 2016 Key Knowledge Gaps for Plasmodium vivax Control and Elimination. American Journal of Tropical Medicine and Hygiene, 95(supplement 6):62-71.

34. Chu, C. and White, N. 2016 Management of Relapsing Plasmodium vivax malaria. Expert Review of Anti-Infective Therapy, 14(10):885-900.

35. Sachs, J. and Malaney, P. 2002 The Economic and Social Burden of Malaria. Nature, 415:680-685.

36. Galinski, M., Meyer, E., and Barnwell, J. 2013 Plasmodium vivax: Modern Strategies to Study a Persistent Parasite's Life Cycle. Advances in Parasitology (81):1-26.

37. Stimson, A.M. 1926 Malaria. Science, 67(1740):449-454.

38. Beeley, A. 1934 The Conquest of Malaria: Its Nature and Social Significance. The Scientific Monthly, 38(3):223-230.

39. Hackett, L.W. 1937 Malaria in Europe: An Ecological Study. London: Oxford University Press.

40. Tchnesvona, L. 1998 Socio-economic and scientific premises for forming the strategies against malaria in Russia under Soviet power. Parassitologia 40:103-108.

41. Hollander, P. 1997 Political Pilgrims: Western Intellectuals in Search of the Good Society. New Brunswick, NJ: Transaction Press.

42. Avetisyan, L. 2002 Re-emergence of Malaria in Armenia and Vector Control Interventions. Journal of Health Sciences Management and Public Health, https://pdfs.semanticscholar.org/36f4/73779a798015b70c270d6b52769cfefeb88d.pdf. Accessed 4 September 2020.

43. Center for Disease Control. Epidemic Malaria Transmission in Armenia, 1997. Morbidity and Mortality Weekly Report.https://www.cdc.gov/mmwr/preview/mmwrhtml/00053695.htm. Accessed 4 September 2020.

44. Bromley, Y. 1974 Ethnographical Studies in the USSR, 1965-1969. In, Soviet Ethnology and Anthropology Today. Yu. Bromley, ed. The Hague: Mouton, pp. 15-30. 
45. Saparov, Arséne 2012 Why Autonomy? The Making of Nagorno-Karabakh Autonomous Region, 1918-1925. Europe-Asia Studies, 64:2: 281-323.

46. Burke, J. 2000 Internal Migration: A Civil Society Challenge. In, Russia's Torn Safety Nets: Health and Social Welfare during the Transition, Field, Mark and Twigg, Judith, eds. New York: St. Martins Press, pp. 211-230.

47. Gall, C. and de Waal, T. 1997 Chechnya: A Small Victorious War. London: MacMillan.

48. Naimark, N. 2010 Stalin's Genocides. Princeton: Princeton University Press.

49. Kaldor, M. 2007 Oil and Conflict: The Case of Nagorno Karabakh. In, Oil Wars, Mary Kaldor, Terry Lynn Karl and Yahia Said, eds. London: Pluto Press, pp. 157-182.

50. Goltz, T. 1998 Azerbaijan Diary. Armonk, New York: M.E. Sharpe.

51. Saroyan, M. and Walker, E. 1997 Minorities, Mullahs and Modernity: Reshaping Community in the Former Soviet Union. Berkeley: University of California.

52. Cheterian, V. 2018 The Uses and Abuses of History: Genocide and the Making of the Karabakh Conflict. Europe-Asia Studies, 0:6:884-903.

53. de Waal, T. 2003 Black Garden: Armenia and Azerbaijan Through Peace and War. New York: New York University Press.

54. Koehler, J. and Zurcher, C. 2003 Potentials of Disorder. Manchester: Manchester University Press.

55. Volkov, V. 2002 Violent Entrepreneurs: The Use of Force in the Making of Russian Capitalism. Ithaca: Cornell University Press.

56. Cheterian, V. 2018 The Uses and Abuses of History: Genocide and the Making of the Karabakh Conflict. Europe-Asia Studies, 0:6:884-903.

57. Glenny, M. 2008 McMafia: A Journey Through the Global Criminal Underworld. New York: Alfred Knopf.

58. Handelman, S. 1995 Comrade Criminal: Russia's New Mafiya. New Haven: Yale University Press.

59. Satter, D. 2003 Darkness at Dawn: The Rise of the Russian Criminal State. New Haven: Yale University Press.

60. Bauman, M., Radeloff, V., Avedian, V., and Juemmerle, T. 2015 Land Use Change in the Caucasus During and After the Nagorno-Karabakh Conflict. Regional Environmental Change, 15(8), pp. 1703-1716.

61. Centers for Disease Control 1998 Endemic Malaria Transmission-Armenia 1997. Morbidity and Mortality Weekly Report July 3, pp. 526-528.

62. Zartman, W. 1995 Introduction. In, Zartman, W., ed. Collapsed States: The Disintegration and Restoration of Legitimate Authority. Boulder: Lynne Reinner, pp. 1-14.

63. Gros, J. 1996 Towards a Taxonomy of Failed States in the New World Order: Decaying Somalia, Liberia, Rwanda and Haiti. Third World Quarterly, 17(3):455-471.

64. Ezrow, N. and Frantz, E. 2013 Failed States and Institutional Decay: Understanding Instability and Poverty in the Developing World. London: Bloomsbury Press.

65. Milliken, J. and Krause, K. 2003 State Failure, State Collapse and State Reconstruction: Concepts, Lessons and Strategies. In, State Failure, Collapse and Reconstruction, Milliken, J. ed. New York: Blackwell Publishing, pp. 1-24.

66. Tishkov, V. 2004 Chechnya: Life in a War-Torn Society. Berkeley: University of California Press.

67. Clunan, A. 2010 Ungoverned Spaces? The Need for Reevaluation. In, Clunan, A. and Trinkaus, H. Ungoverned Spaces: Alternatives to State Authority in an Era of Softened Sovereignty. Stanford: Stanford University Press, pp. 3-16.

68. Romi, R. Boccolini, D. Hovanesyan, G, Grigoryan, M., Di Luca, M., and Sabatinelli, G. 2002 Anopheles sacharovi (Dipteria: Culicidae): A Reemerging Malaria Vector in the Ararat Valley of Armenia. Journal of Medical Entomology, 39(3):446-450.

69. Bardi, A. 2020 Make Armenia Green Again. Foreign Policy, https://foreignpolicy.com/2020/02/18/armenia-10-million-trees-environmentborders/. Accessed 28 June 2020.

70. Bonner, R. 1993 Wars Envelop Armenia, Corroding Environment. New York Times, August 13. https://www.nytimes.com/1993/08/17/world/wars-envelop-armenia-corroding-environment.html?searchResultPosition=4. Accessed 28 June 2020. 
71. Wines, M. 2001 Trying to Tell a Truce from a War. New York Times, 27 May https://www.nytimes.com/2001/05/27/world/trying-to-tell-a-trucefrom-a-war.html?searchResultPosition=1. Accessed 28 June 2020.

72. Harris, D. 1965 Review of Atlas Narodov Mira, Geographical Review 55(5):608-610.

73. Temel, T. 2007 Malaria from the Gap: Need for Cross-Sector Cooperation in Azerbaijan.

SSRN: https://ssrn.com/abstract=986502 or http://dx.doi.org/10.2139/ssrn.986502 Accessed 3 September 2020.

74. UCSF Malaria Atlas Project 2015 Eliminating Malaria in Azerbaijan.

http://www.shrinkingthemalariamap.org/sites/www.shrinkingthemalariamap.org/files/content/resource/attachment/Azerbaijan2016_Final.pdf Accessed 7 September 2020.

75. Azerbaijan Threatens Chernobyl-Style 'Catastrophe' in Caucasus Drone War. Forbes.

https://www.forbes.com/sites/davidhambling/2020/07/17/threat-of-chernobyl-style-catastrophe-in-caucasus-drone-war/\#4bfb8c2f7946.

Accessed 7 September 2020.

76. BBC News https://www.bbc.com/news/world-europe-54323553 Accessed 28 September 2020.

\section{Figures}

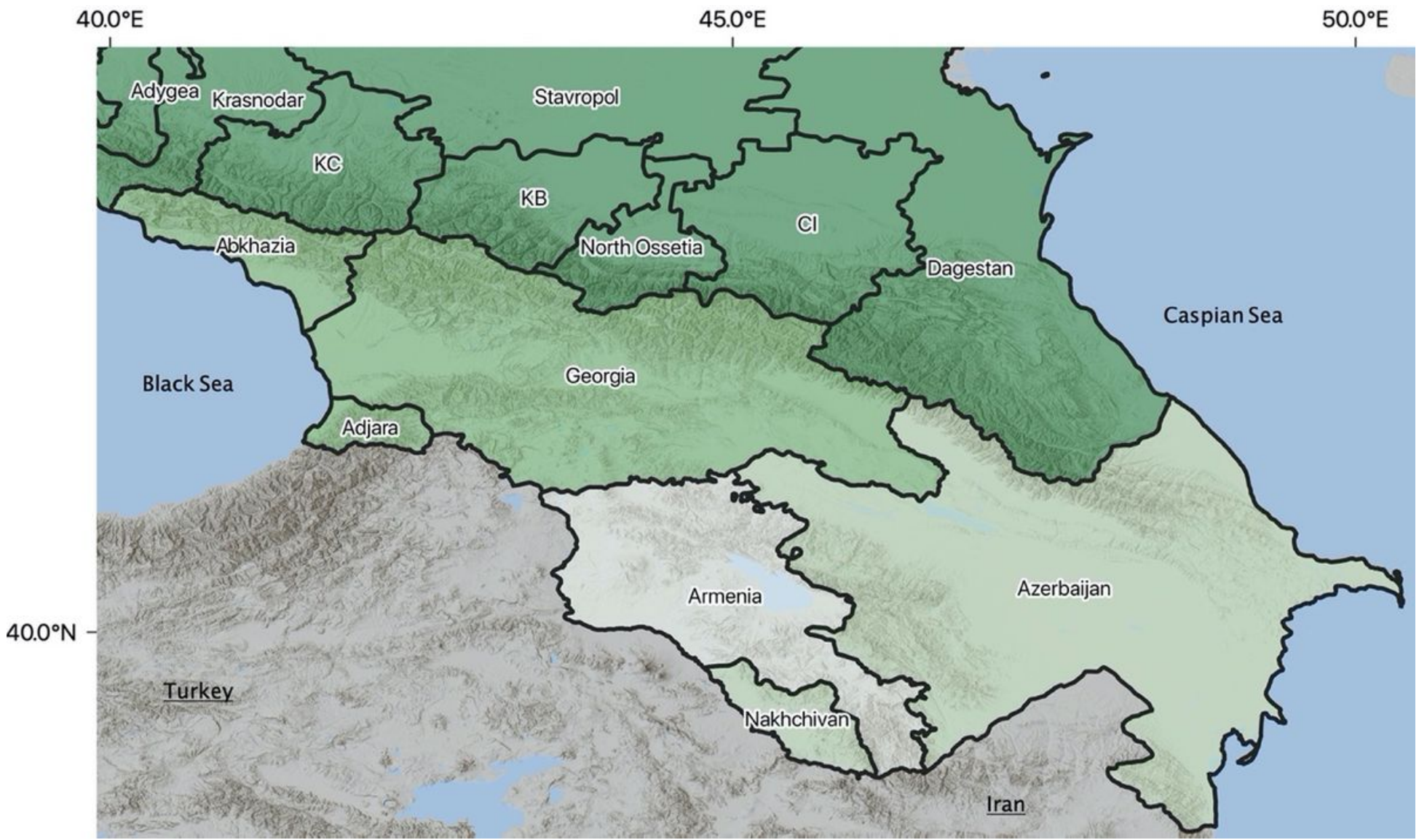

\section{Figure 1}

Soviet Administrative Territories in the Caucasus, ca. 1989, before the collapse of the Soviet Union. Lightly shaded areas were SSRs or Soviet Socialist Republics, which had a greater degree of independence from Moscow than Autonomous Republics (ASSRs, shaded in light green). AOs (Administrative Oblasts, shaded in darker green) were territorial subunits and not considered to have unique nationality. Note: The designations employed and the presentation of the material on this map do not imply the expression of any opinion whatsoever on the part of Research Square concerning the legal status of any country, territory, city or area or of its authorities, or concerning the delimitation of its frontiers or boundaries. This map has been provided by the authors. 


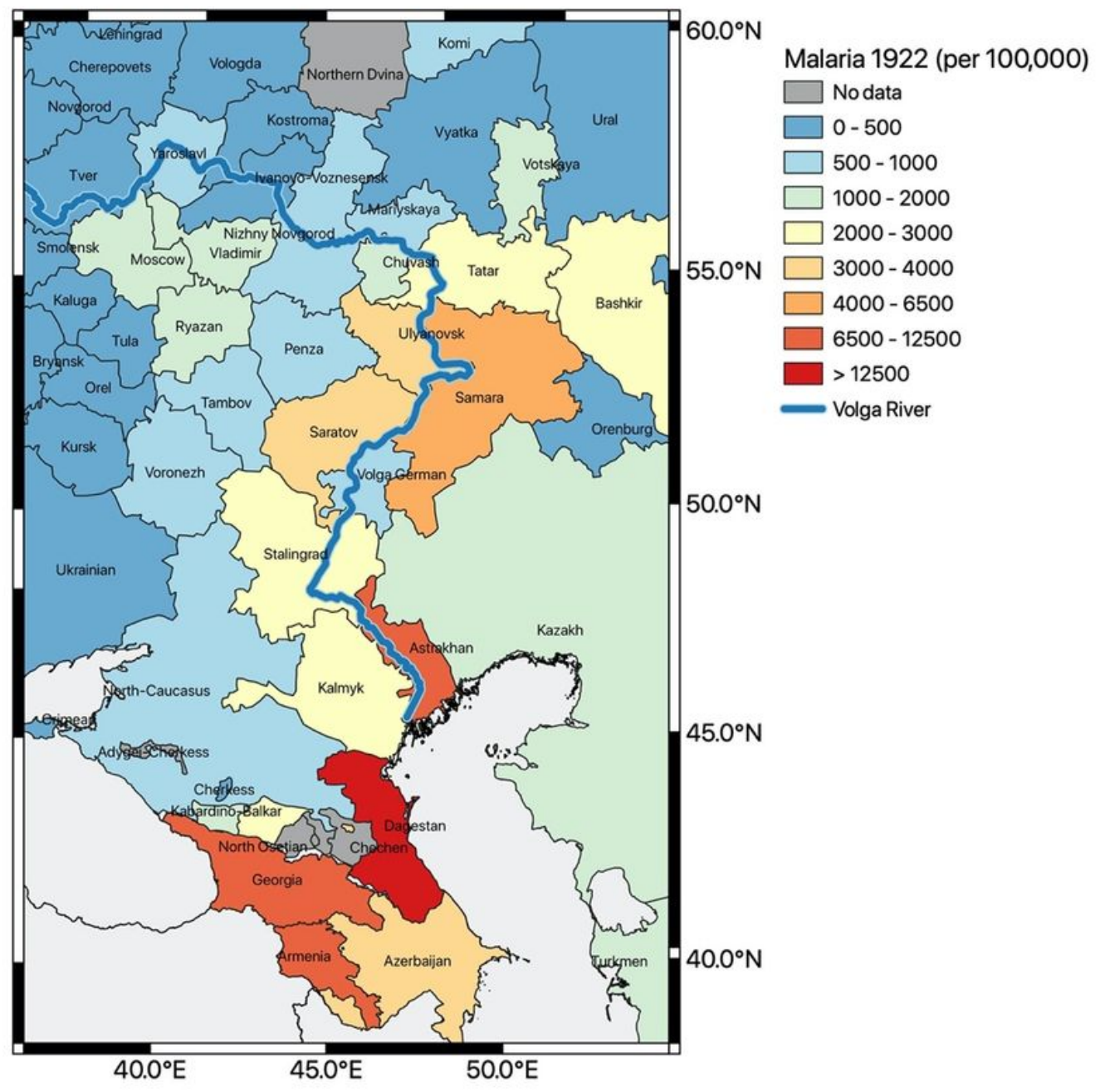

Figure 2

Soviet administrative boundaries and malaria prevalence per 100,000 population in the Caucasus region before the Soviet malaria eradication campaign, 1922. The Volga River drainage area (illustrated in red) had the highest rates in the region. Note: The designations employed and the presentation of the material on this map do not imply the expression of any opinion whatsoever on the part of Research Square concerning the legal status of any country, territory, city or area or of its authorities, or concerning the delimitation of its frontiers or boundaries. This map has been provided by the authors. 


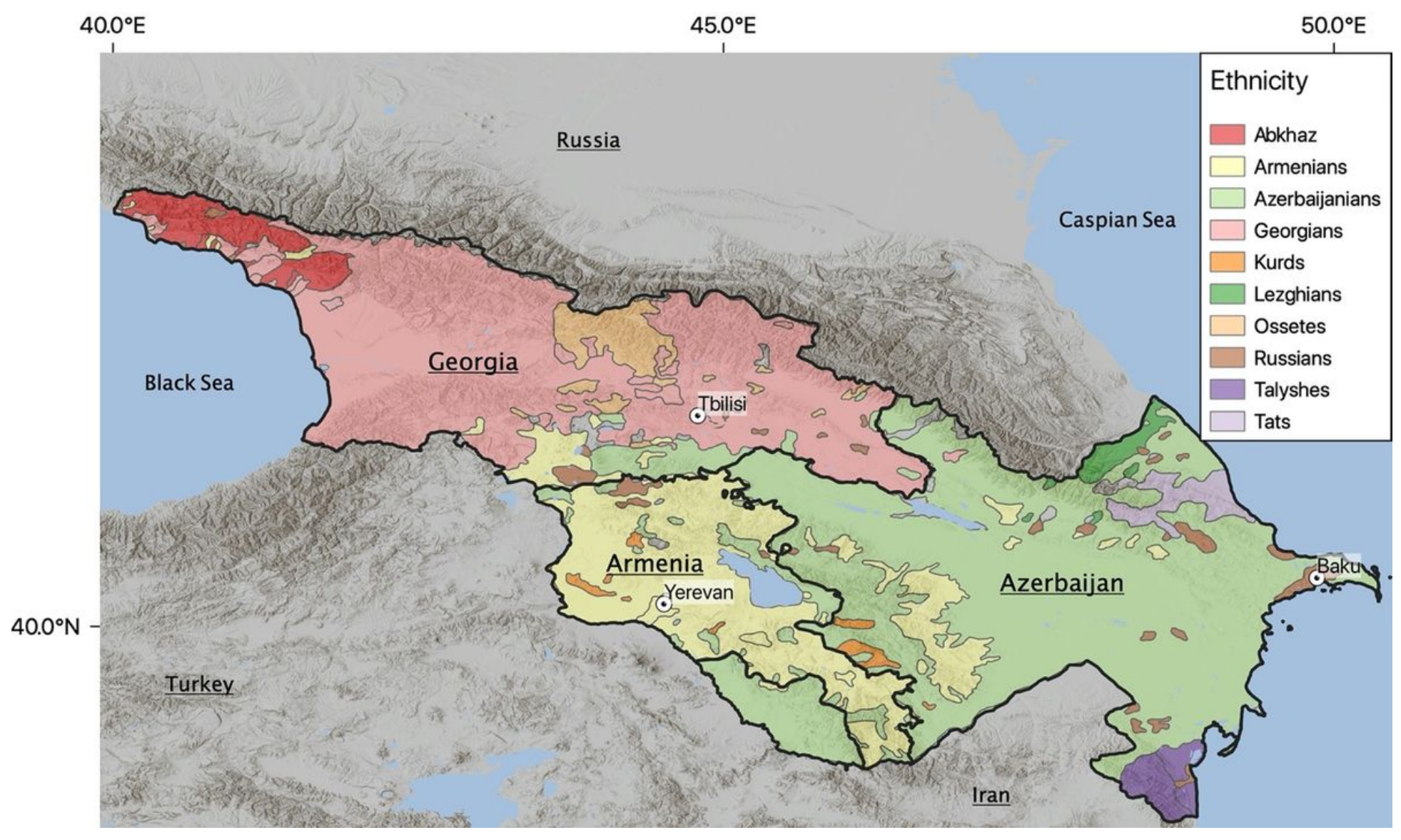

\section{Figure 3}

Major ethnic groups and associated territories in the south Caucasus region during the Soviet era. Note: The designations employed and the presentation of the material on this map do not imply the expression of any opinion whatsoever on the part of Research Square concerning the legal status of any country, territory, city or area or of its authorities, or concerning the delimitation of its frontiers or boundaries. This map has been provided by the authors. 


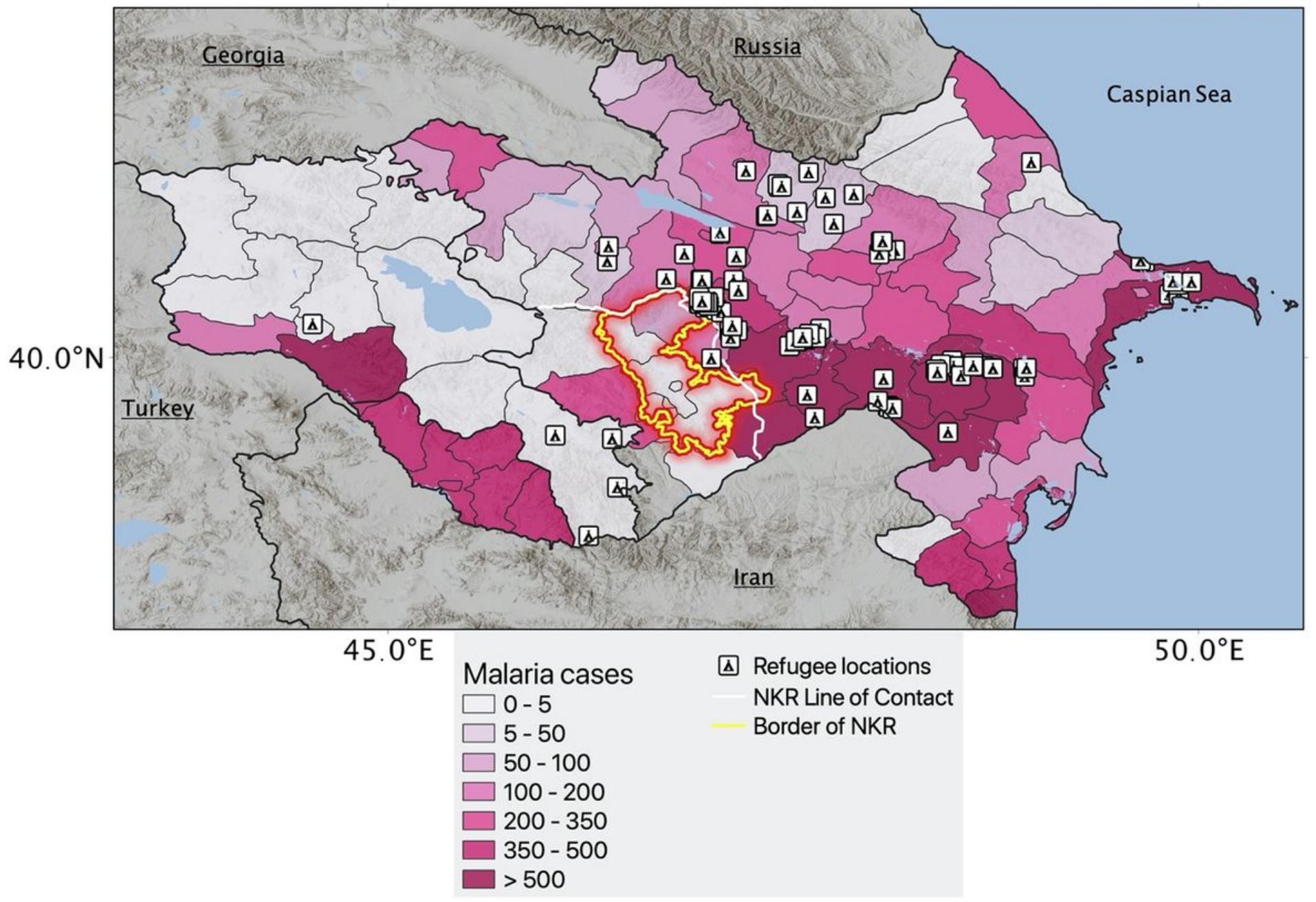

\section{Figure 4}

Map detailing density of malaria cases and refugee settlements on the periphery of the main conflict zone in Nagorno-Karabakh, 1991 (NGK, highlighted in yellow border). Note: The designations employed and the presentation of the material on this map do not imply the expression of any opinion whatsoever on the part of Research Square concerning the legal status of any country, territory, city or area or of its authorities, or concerning the delimitation of its frontiers or boundaries. This map has been provided by the authors. 


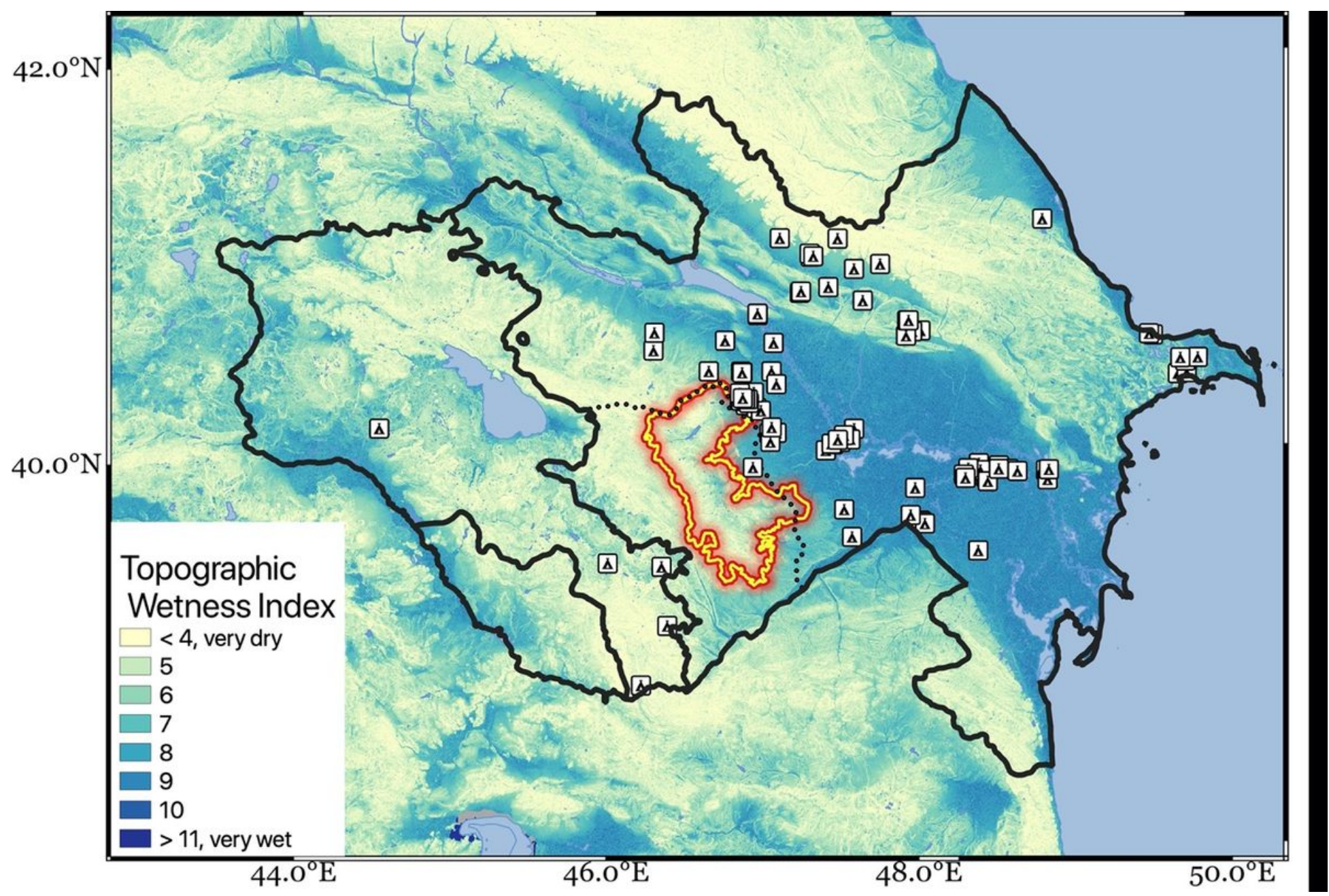

Figure 5

Topographic wetness index for present-day Armenia, Azerbaijan and the contested Nagorno-Karabakh region (outlined in yellow). This map indicates the level of water run off that collects on the land surface. Note: The designations employed and the presentation of the material on this map do not imply the expression of any opinion whatsoever on the part of Research Square concerning the legal status of any country, territory, city or area or of its authorities, or concerning the delimitation of its frontiers or boundaries. This map has been provided by the authors. 